Oper Tech Thorac Cardiovasc Surg. 2013 Winter;18(4): 305-15.

Op Techs: Valve-sparing Options in Tetralogy of Fallot Surgery-Emile Bacha. Oper Tech Thorac Cardiovasc Surg. 2013 Winter;18(4):316-27.

Op Techs: Heart Transplant: Transplantation for Congenital Heart Disease-Jonathan Chen. Oper Tech Thorac Cardiovasc Surg. 2014 Spring;19(1):30-46.

Op Techs: Implantation of HeartWare Left Ventricular Assist Device in Pediatric Population-Vivek Rao. Oper Tech Thorac Cardiovasc Surg. 2014 Spring;19(1):80-95.

\section{CARDIOPULMONARY TRANSPLANTATION AND MECHANICAL CIRCULATORY SUPPORT}

Seminars: Editorial: The 1000th VAD, The Great Rivalry, and the Grand Experiment of the Texas Medical CenterTodd Rosengart. Semin Thorac Cardiovasc Surg. 2014 Sping;26(1):1-3.

Seminars: News and Views: Mechanical Circulatory Assist Device Development at the Texas Heart Institute-O. Howard Frazier. Semin Thorac Cardiovasc Surg. 2014 Spring;26(1):4-13.

Op Techs: Heart Transplantation after Left Ventricular Assist Device-Carmelo Milano. Expected publication November 2014.

Op Techs: Bilateral lung transplantation-evolution to simplify-Mani Daneshmand. Expected publication November 2014.

Op Techs: Ambulatory ECMO, VV, VA, and VV-VACharles Hoopes. Expected publication November 2014.
Op Techs: Techniques for DCD Organ ProcurementPankaj Saxena. Expected publication December 2014.

Op Techs: VA ECMO techniques, peripheral and central for cardiogenic shock-Ashok Babu. Expected publication December 2014.

Op Techs: Non-sternotomy approaches to LVAD Placement-Left Thoracotomy-Simon Maltais. Expected publication December 2014.

Op Techs: Non-sternotomy approaches to LVAD placement-Left subcostal and right mini-thoracotomyAnelechi Anyanwu. Expected publication December 2014.

\section{EVOLVING TECHNOLOGY AND BASIC SCIENCE}

Seminars: State of the Art: The Promise and Challenges of Cardiac Stem Cell Therapy-Richard Weisel. Semin Thorac Cardiovasc Surg. 2014 Spring;26(1):44-52.

\section{CARDIOTHORACIC EDUCATION AND TRAINING}

Seminars: News and Views: Integrated Surgical Residency Initiative: Implications For Cardiothoracic Surgery-John Ikonomidis and Editorial Commentary-Ara Vaporciyan. Semin Thorac Cardiovasc Surg. 2014 Spring;26(1):14-26.

Seminars: News and Views: The Affordable Care Act: Implications for Cardiothoracic Surgery-T. Bruce Ferguson. Semin Thorac Cardiovasc Surg. 2013 Winter;25(4):280-6.

Seminars: Discussion in Cardiothoracic Treatment and Care: Manpower-Richard Shemin, David Fullerton, John Ikonomidis, John Mayer, Cameron Wright. Expected publication December 2014.

\section{The Western Thoracic Surgical Association}

\section{The WTSA 2014 Annual Meeting in Review}

The 40th Annual Meeting of the Western Thoracic Surgical Association was held at the St. Regis Monarch Beach in Dana Point, California, June 25-28, 2014. The meeting included oral presentation of 20 original papers, panel discussions, a postgraduate course, additional invited speaker sessions, and 24 other papers presented during concurrent forums in the disciplines of adult cardiac, general thoracic, and congenital heart disease. The Annual Meeting attracted 230 physicians and allied health professionals and provided an outstanding educational program with ample opportunities for open discussion, scientific debate, and the collegiality characteristic of the WTSA Annual Meeting.

Educational highlights of the program included the C. Walton Lillehei Point/Counterpoint Session, entitled "Pay-for
Performance vs. Criteria-Based Systems in the U.S. and Canada" and moderated by David A. Fullerton with Jeffrey B. Rich presenting the U.S. perspective and Alan H. Menkis presenting the Canadian side. In addition, the Presidential Address, given by Thomas A. Burdon, was entitled "Witness to the Wonder Years: Innovation to Transformation."

Marvin Pomerantz reflected "On the 40th Anniversary of the WTSA," and the Western incorporated its Spouse Forum into the main program, with Frédéric Luskin providing instruction on "Making Yourself Just a Little Happier."

The Postgraduate Course, titled "From Checklists to Culture, What Spacewalking Brings to Surgery" and sponsored by White Memorial Medical Center and Foundation, Lyman A. Brewer III, Fund, as well as by a donation from Thomas J. Fogarty, featured David Williams from the Southlake Regional Health Centre in Newmarket, Ontario. Astronaut and physician Dr Williams explored the principles of leadership in high-reliability organizations and the applicability of 


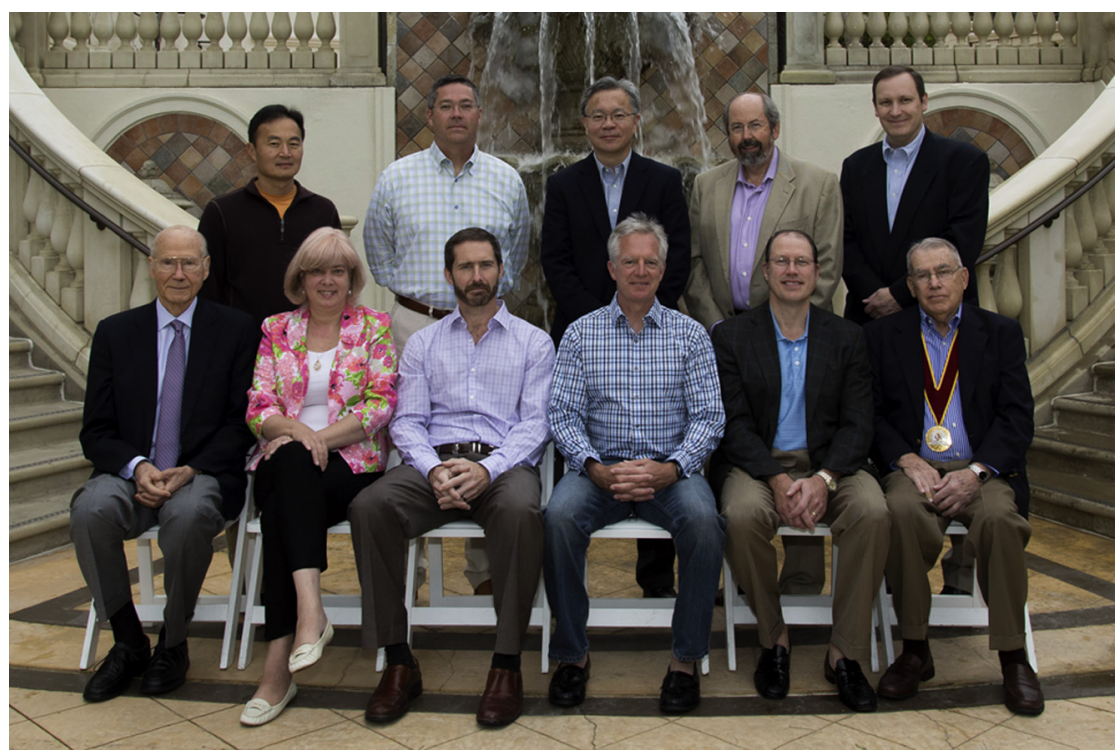

2013-2014 WTSA Council (seated, left to right) Arthur N. Thomas, Patricia A. Thistlethwaite, Michael S. Mulligan, Thomas A. Burdon, Joseph C. Cleveland, Jr, and Marvin Pomerantz; (standing, left to right) John C. Chen, John D. Mitchell, James I. Fann, Mark T. Metzdorff, and Sean C. Grondin; (missing) Lawrence H. Cohn.

these principles to the zero-fault-tolerant environment of spacewalking and surgery.

A special invited speaker session addressed "Catheter-Based Mitral Valve Replacement: What Is It and Is It Possible"; the panel included Anson Cheung and Saibal Kar and was moderated by Michael P. Fischbein. Additional invited speakers included Jonathan Michael Chen who provided an "Update on Pediatric VADs," and Craig J. Baker and James I. Fann who presented "Simulations in Cardiac Surgery."

Several awards were presented during the meeting. The David J. Dugan Distinguished Service Award was presented posthumously to Harold C. Urschel, Jr, of Baylor University Medical Center in Dallas, for his distinguished achievements in cardiothoracic surgery. In addition, the Donald B. Doty Educational Award was given to Nahush A. Mokadam, from the University of Washington Medical Center in Seattle, for his proposal, "Cardiopulmonary Bypass Mobile Application"; the Norman E. Shumway Award for the Best Paper co-authored by a WTSA member was awarded to Stephanie G. Worrell of the University of Southern California, Los Angeles, for her presentation "The Impact of Adjuvant Therapy on Recurrence and Survival Following Primary Esophagectomy for Adenocarcinoma"; and the Samson Resident Prize Essay Award was given to Jatin Anand of Baylor College of Medicine, Houston, for "Continuous-Flow Ventricular Assist Device Exchange: A Single-Center Experience."

The 2014-2015 Officers elected during the meeting include: President Michael S. Mulligan, Seattle, Washington; Vice President John D. Mitchell, Aurora, Colorado; Secretary Patricia A. Thistlethwaite, La Jolla, California; Treasurer Joseph C. Cleveland, Jr, Aurora, Colorado; Councillor
Thomas A. Burdon, Stanford, California; Councillor-atLarge Richard I. Whyte, Boston, Massachusetts; Historian Marvin Pomerantz, Tucson, Arizona; and Editor Richard D. Weisel, Toronto, Ontario, Canada.

Also during the 40th Annual Meeting, 32 new members were elected to WTSA membership-21 to Active membership and 11 to Candidate membership: Errol L. Bush, San Francisco, California (Candidate); Neil Cambronero, San Francisco, California (Candidate); David J. Caparrelli, Flagstaff, Arizona; Hannan Chaugle, Richland, Washington; Jonathan M. Chen, Seattle, Washington; Aaron M. Cheng, Seattle, Washington; Hannah Copeland, Loma Linda, California (Candidate); Jacob DeLaRosa, Pocatello, Idaho; Daniel J. DiBardino, San Diego, California; Fernando Fleischman, Los Angeles, California; Rabin Gerrah, Portland, Oregon; John M. Karamichalis, San Francisco, California; Tara Karamlou, San Francisco, California; Ali Khoynezhad, Los Angeles, California; Richard W. Kim, Los Angeles, California; Sam Kim, Tucson, Arizona (Candidate); Elbert Y. Kuo, Phoenix, Arizona; Robroy MacIver, Minneapolis, Minnesota (Candidate); David Ogden, San Jose, California; Amy Rahm, Sacramento, California (Candidate); Dan J. Raz, Duarte, California (Candidate); Ahmad Y. Sheikh, Stanford, California (Candidate); Ramesh Singh, Falls Church, Virginia; Sreekumar Subramanian, Tucson, Arizona; Jack C. Sun, Seattle, Washington; Benedict J. W. Taylor, Santa Barbara, California; Jess Thompson, Tucson, Arizona; Simon Turner, Vancouver, British Columbia (Candidate); Melita L. Viegas, Los Angeles, California (Candidate); Dustin M. Walters, Seattle, Washington (Candidate); Thomas J. Watson, Rochester, New York; and Joseph Woo, Stanford, California. 